$11-16-2003$

\title{
Expert Testimony And Scientific Evidence
}

Lynn McLain

University of Baltimore, lmclain@ubalt.edu

Follow this and additional works at: http://scholarworks.law.ubalt.edu/all_fac

Part of the Evidence Commons

\section{Recommended Citation}

Lynn McLain, Expert Testimony And Scientific Evidence, (2003).

Available at: http://scholarworks.law.ubalt.edu/all_fac/922

This Article is brought to you for free and open access by the Faculty Scholarship at ScholarWorks@University of Baltimore School of Law. It has been accepted for inclusion in All Faculty Scholarship by an authorized administrator of ScholarWorks@University of Baltimore School of Law. For more information, please contact snolan@ubalt.edu. 


\section{EXPERT TESTIMONY AND SCIENTIFIC EVIDENCE \\ Maryland Judicial Institute \\ October 16, 2003 \\ The Honorable Paul Grimm and Professor Lynn McLain}

\section{Agenda}

Page

1:00 - 1:10 p.m.

Introduction - The Honorable Paul Grimm

$1: 10-2: 30$ p.m.

- When is Expert Testimony Appropriate? Necessary? . . . . . . . . . . . . . . 1

- When is Opinion Testimony Permitted, Whether Expert or Lay? . . . . . . . . . 4

- Opinions in Out-of-Court Statements . . . . . . . . . . . . . . . . . 10

- Who Is, and Who May Testify as, an Expert? . . . . . . . . . . . . . 11

- May/Must the Expert Testify at Trial to the Factual Basis of His/Her Opinion? . . . . . . . . . . . . . . . . . . . . . . . . 14

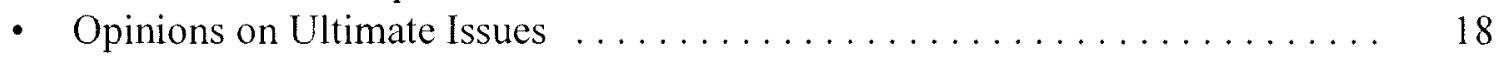

$2: 30-2: 45$ p.m.

Break

$2: 45-4: 00$ p.m.

- Sufficient Basis for Expert Testimony: Generally, 5-401, 5-702,

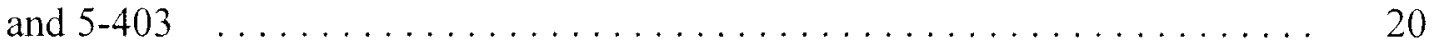

- Scientific Evidence ................................ 24

- Frye-Reed vs. Daubert/Kumho Tire: How Do They Work? Which is Better?

4:00- 4:15 p.m.

Questions and Discussion 


\section{EXPERT TESTIMONY AND SCIENTIFIC EVIDENCE \\ Maryland Judicial Institute \\ October 16, 2003 \\ Professor Lynn McLain \\ University of Baltimore School of Law}

\section{Underlying Goals of the Rules of Evidence in General}

- Getting as close to the truth as possible, while maximizing efficiency, so as to obtain maximum fairness with minimum expenditure of court time.

- Admit only evidence relevant to issues in the case.

- Do best to exclude unreliable evidence (but rely on cross as to matters of credibility of witnesses).

\section{Expert Testimony}

\section{§ 1. The Rules Regarding Expert Testimony: When, What, Who, and How?}

- The question of when to permit expert testimony, and on what subjects, is governed by Md. Rules 5-401, 5-403, and 5-702.

- Who may testify as an expert is governed by Rules 5-702 and 5-706.

- How experts' testimony is elicited is governed by Rules 5-703, 5-704, and 5-705.

\section{General References:}

Paul W. Grimm, Maryland EvidenCe Checklists (MICPEL 1989) (lay opinions, 20; experts, 21).

JoSEPH MuRPhy, Maryland EVIDENCE HANDBOOK (3d ed. 1999) ( $\$ 567($ A), Statistical probability; $\S \S 1400-1409$, Expert testimony).

LYNN MCLAIN, Maryland EVIDENCE: State AND FEDERAl (2d ed. 2001 \& Supp. 2003), vols. 5, 6, and 6A of West's Maryland Practice Series:

vol. 5: $\$ 201: 1-: 5$, Maryland state law regarding taking judicial notice.

$\S 201: 6$, federal law regarding taking judicial notice.

$\S 300: 7$, effect of introduction of expert testimony, and when expert testimony is needed to meet the burden of production of the evidence.

$\$ 401: 4$, Maryland state law regarding scientific evidence.

$\$ 401: 8$, federal law regarding scientific evidence.

vol. 6: $\$ 701: 1-7$, Maryland state law regarding lay opinion testimony. 
$\$ 701: 8$, federal law regarding lay opinion testimony.

$\S \S 702: 1-: 5,703: 1,704: 1,705: 1,706: 1$, Maryland state law regarding experts.

$\S \S 702: 6,703: 2,704: 2,705: 2,706: 2$, federal law regarding experts.

Lynn MClain, Maryland Rules of Evidence (2d ed. 2002), vol. 7 of West's Maryland Practice Series (rules with brief commentary).

\section{$\S 2$. When is Expert Testimony Appropriate?}

\section{a. In General}

At earlier common law, expert testimony was permitted only if the subject was so beyond the ken, the understanding and experience, of the average juror that the jury could not begin to interpret the facts on its own.

The modern rule, however, is not so strict: as codified in the second clause of $\mathrm{Md}$. Rule 5-702, it provides that expert testimony will be admissible if it "will assist the trier of fact to understand the evidence or to determine a fact in issue..." Whether the evidence will be helpful - as well as whether a particular witness is qualified as an expert - is decided by the trial court, in its discretion.

\section{b. Possible Rulings as to Helpfulness/Admissibility}

When expert testimony is offered, there are three possible results under Rule 5-702.

(1) The first is that proffered expert testimony is inadmissible, because it would not assist the jury. This can be because of one of two reasons:

Either (a) The jury would not need it at all to objectively evaluate the facts. .

Example: $\quad$ Truck Ins. Exchange v. Marks Rentals, Inc., 285 Md. 428 (1980) (abuse of discretion to allow insurance expert's testimony as to meaning of contract clause, "passenger cars he may rent to others or operate under his Thrifty Rent-A-Car franchise," when the words used had no technical meaning).

or (b) The proffered expert opinion has an insufficiently reliable basis (e.g., "junk science"). This possibility will be explored further in parts IX.-X. infra.

(2) A second possibility is that the court or the jury needs expert testimony, because common sense and logic are insufficient to evaluate the facts. Expert testimony is not only admissible, it may be necessary in order for a party to meet its burden of production of the evidence, so as to withstand a motion for judgment. 
Examples: (I) In a medical malpractice case, $\mathrm{P}$ offers testimony of a lab technician that a pre-operation blood test showed that the osmillality in P's blood was 480 micromoles per second. (What significance, if any, has this evidence? An expert's explanation is needed.)

(ii) Hricko v. State, 134 Md. App. 218 (2000) (a Shakespearean odyssey by Judge Charles Moylan about the real murder during a St. Michaels, MD murder-mystery-weekend) (medical examiner may testify that cause of death was probably poisoning, by an unidentified substance), cert. denied, 362 Md. 188 (2000).

(3) A third possibility is that the party does not need expert testimony to meet its burden of production, but it would be helpful to the fact-finder. In this situation, expert testimony will be admissible, in the court's discretion.

\section{Problem.}

1. Determine which of the above three standards applies to each of the following scenarios from an early dental malpractice case, Toy v. Mackintosh, 110 N.E. 1034 (Mass. 1916).

P-Patient sued D-Dentist for negligence in letting a tooth fall down P's throat. P testifies he had several teeth extracted by $D$ while $P$ was under an anesthetic, and that nine weeks later P coughed up a tooth (which he entered into evidence).

a. D moves for a directed verdict, on the ground that $P$ failed to offer any expert testimony regarding breach of duty. Should the motion be granted?

b. D testifies to his own skill and experience and wishes to call other experts to testify to precautions routinely taken and, in effect, that P's inhaling of a tooth is consistent with due care. Should the court let in the expert testimony?

c. At the close of D's case, D again moves for a directed verdict, on the ground that his expert testimony "beats" P's testimony. Should his motion be granted? 
d. Consider also the issue of causation of damages. $P$ testified that he was in good health before the dental surgery. Soon after the operation, he developed a cough and severe pain in the left side of his body. Subsequently, he lost part of his ability to speak, grew dizzy, and his right arm and leg were numb. These symptoms continued at trial, although after he coughed up the tooth, his cough was immediately relieved. D's experts testify that the non-cough symptoms had nothing to do with the tooth and were caused instead by two shocks that $\mathrm{P}$ had received. $\mathrm{D}$ moves for a directed verdict on the damages issue regarding everything but the cough. Should the motion be granted?

See Giant Food, Inc. v. Booker, 2003 WL 22051771 *6-7 (Md. App. Sept. 3, 2003)

(absent a close temporal relationship between Freon incident and onset of asthma, expert testimony was needed to meet plaintiff's burden of production).

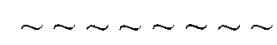

\section{The Test as to Opinion Testimony, Whether Expert or Lay}

No matter whether lay opinion (Rule 5-701) or expert opinion (Rule 5-702), the test for admissibility is whether the opinion is rationally based and will be helpful to the jury (or to the court as factfinder).

By virtue of Rule 5-704(a), there is no longer a per se rule barring legal conclusions. The question remains, rather, one of helpfulness.

A synthesis of the case law generates the following factors to be used in evaluating whether an opinion should be admitted:

1. Is the opinion supported by a sufficient rational basis? Or, for example, is it merely speculation or conjecture? If a lay opinion, would the witness need to be an expert to reach a rational opinion?

2. Will the opinion provide more information than the jury could get otherwise? Or will it be merely superfluous, so that the jury could figure it out just as well for itself? In that event, we want to avoid the possibility of undue influence on the jury by admitting opinion testimony.

3. Will opinion testimony provide the most efficient and practical way for the jury to hear the evidence? Or could the testimony be helpfully ratcheted back to the underlying facts, so that we leave the jury to reach the conclusion on its own? (Let the jury "connect the dots.") See, e.g., Cook v. State, 84 Md. App. 122, 135-44 (1990) (reversible error to allow police officer to give expert opinions as to each defendant's role in drug 
operation; expert should have testified only "that the head of the organization is usually armed and usually has the organization's money on his person" and let the jury make further findings).

For good reason, therefore, the standard of appellate review is abuse of discretion. Robinson v. State, 348 Md. 104, 115-28 (1997); Hartless v. State, 327 Md. 558, 572-81 (1992).

\section{Problems.}

2. Plaintiff calls witness to testify that storeowner's leaving a barrel on the sidewalk outside his store was negligent. Admit?

Brunker v. Cummins, 32 N.E. 732 (Ind. 1892). See also American Mut. Ins. Co. v. Bittle, 26 Md. App. 434, 442 (1975).

3. A lay witness is called to testify that she saw bloodstains on her roommate's shirt. Admit?

See Daniels v. State, 213 Md. 90, I05 (1957).

4. Buddy of defendant is called to testify that he was with defendant and that, although the defendant had had a couple of drinks, he was not drunk. Admit?

See Cumberland \& Westernport Transit Co. v. Metz, 158 Md. 424, 451, 453-54 (1930); Crampton v. State, 71 Md. App. 375, 388 (1987), aff'd on other grounds, 314 Md. 265 (1988).

5. Friend of victim is called to testify that when defendant visited victim and friend at friend's house the day before victim's murder, the defendant was shouting and angry at the victim. Admit?

See Lawson v. Ward, 153 Md. 93, 98 (1927).

6. In CINA proceeding, State calls mother-in-law of mother to testify that mother is a terrible housekeeper and that her home has always been filthy whenever motherin-law has visited. Admit?

And that daughter-in-law is "unfit to be a mother." Admit?

7. In rape case, State's expert wishes to testify that rape victims often suffer PTSD. Admit? And that, indeed, the victim suffers from Post Traumatic Stress Disorder, caused by rape. Admit? 
The Court of Appeals in State v. Allewalt, 308 Md. 89 (1986), stressed that the doctor did not use the term "rape trauma syndrome" and thus did not "equate the syndrome exclusively with rape." While the majority found no abuse of discretion in the trial court's admission of the PTSD evidence in Allewalt, it cautioned that questions were left unanswered, such as whether a defendant could prove the absence of PTSD, and stated that in the future:

When ruling on whether to receive State proffered evidence of PTSD a trial judge will have to weigh the benefit of the evidence not only against potential unfair prejudice, but also against the complexity of possibly accompanying issues and against the time required properly to try the expanded case.

$308 \mathrm{Md}$. at 110 (emphasis added). See Acuna v. State, 332 Md. 65, 68-71 (1993) (in child sexual abuse prosecution, clinical psychologist's testimony that child's observed behaviors were consistent with Post-Traumatic Stress Disorder was admitted properly, under Allewalt, when expert "was able, through history, to connect the PTSD to the criminal conduct charged").

See also Hutton v. State, 339 Md. 480 (1995) (reversible error to permit expert testimony that alleged sexual child abuse victim suffered from PTSD that was "not in any way faked," when basis of opinion was statements of child and it was, in effect, a comment on the victim's credibility; Allewalt was distinguished on ground that expert there was simply asked to "assume the victim's truthfulness") (Rodowsky, J., concurring, joined by Murphy C.J., disagreed, pointing out that excluding an expert's opinion, when it has a basis, part of which is the patient's history, has not been the law in Maryland; to reach a diagnosis of PTSD, the expert must find that the described stressor occurred).

In Hall v. State, 107 Md. App. 684, 691-92 (1996), cert. denied, 342 Md. 473 (1996), remanded to the Court of Special Appeals for reconsideration in light of Hutton, then Judge Joseph Murphy summarized Hutton as follows:

Hutton... prohibits counsel from (1) asking a witness directly whether he or she personally believes the testimony of another person, and (2) introducing expert testimony in a way that presents the trier of fact with an expert's assertion of personal belief that another person's testimony is true. Nothing in Hutton, however, prohibits an expert from opining that the child's behavioral problems are consistent with abuse.

The Hall court concluded, therefore, that the trial court had not committed error in permitting the state to elicit an expert's opinion that "there was a strong cause-effect relationship between child abuse and the disorders from which the victim was suffering" (although the better form for the opinion would have been that "the victim's disorders 'are consistent' with disorders found in children who have suffered sexual child abuse"). 107 Md. App. at 695.

The defense in Hall was that the child victim's charges were "fabrications or imaginations" and that the child was unworthy of belief because of conduct and stress disorders, the latter perhaps caused by having been placed in four different foster homes. Under the facts of the case, "[t]he State was entitled to guard against the risk that the trier of fact would commit an 'untutored layman's error of dismissing as non-credible testimony that, in the arcane context of child abuse, should not be so readily dismissed." Id.

8. Child who was in next room and could not see shooter is called to testify that her stepfather said nothing but pointed gun straight at her mom and then shot her mother. Admit? 
9. Expert mechanical engineer who specialized in researching automotive safety, particularly vehicle ejections and door latch failures, has examined latch on decedent's 1992 Dodge Ram pickup and wishes to testify that the latch was not state of the art or state of the industry in 1992 and that it is his opinion, to a reasonable degree of engineering certainty, that a state of the industry latch would have prevented door from opening in crash. Admit?

Clark v. Chrysler Corp., 310 F.3d 461 (6th Cir. 2002), cert. filed, 71 U.S.L.W. 3760 (May 2003).

10. Defendant was charged with making threats against the President. Defendant had sent anti-Pres. Clinton communications to defendant's neighbors, some businesses, and some state and local governmental organizations, which forwarded them to the police and the Secret Service. The government was required to prove that a reasonable person would foresee that his statements would be interpreted as threats by those to whom the defendant communicated. It called three Secret Service agents and one police commander to testify that the writings were significant threats to the President. Admit?

United States v. Hanna, 293 F.3d 1080 (9th Cir. 2002).

11. Police officer wishes to testify that victim made no inconsistent statements during her several interviews. Admit?

Robinson v. State, 151 Md. App. 384, 393-95 (2003).

12. Wrongful death plaintiff wishes to call a toxicology expert to testify to effect of defendant truck driver's smoking some marijuana eight hours before accident.

\section{Admit?}

Bocanegrav. Vicmar Services, Inc., 320 F.3d 58 I (5th Cir. 2003).

13. Psychiatric expert's testimony as to effects of illegal searches on fans at a basketball tournament. Admit?

Williams v. Brown, 244 F.Supp.2d 965 (N.D. 1ll. 2003).

14. In antitrust suit, both plaintiff and defendant offer expert testimony regarding economic principles, such as effect of higher liquor prices on consumption of alcoholic beverages. Admit?

TFWS, Inc. v. Schaefer, 325 F.3d 234 (4th Cir. 2003).

15. In kidnapping and interstate domestic violence case, when victim testified inconsistently with her grand jury testimony, her 911 calls, and her written 
statement, prosecution offered expert testimony regarding domestic abuse victims' frequent recantations, as well as their inability to perceive means of escape. The expert, a psychiatric mental health nurse who specialized in crime victims, had interviewed the victim personally, reviewed police reports of other confrontations between victim and defendant, and listened to recordings of their conversations while defendant was in pre-trial detention. Admit?

United States v. Young, 316 F.3d 649 (7th Cir. 2002). Cf. Yount v. State, 99 Md. App. 207 (1994) (no abuse of discretion to admit, in rebuttal, expert testimony by a psychologist about the fact that recantation by child sexual abuse victims of their initial reports, while still exposed to family members, and subsequent retraction of the recantation once the child's support systems were in place, was "both normal and very common").

Opinions on the credibility of a witness's testimony in the case, however, are precluded. E.g., Bentley v. Carroll, $355 \mathrm{Md}$. 312, 332-39 (1999) (trial court erred in permitting defense psychiatrist to testify that, based on MMPI, plaintiff was exaggerating her claims); Bohnert $v$. State, $312 \mathrm{Md}$. 266 (1988) (under circumstances, admitting expert opinion that child had been sexually abused, based only on what victim had said, was an abuse of discretion; but also, as an "alternative reason," the opinion was inadmissible "as a matter of law" because it was an opinion that child's testimony was credible); Snyder v. State, 104 Md. App. 533, 551-54 (1995) (reversible error to permit police detective to testify as to questions he had for defendant, which clearly showed his disbelief of defendant's story). But cf. Nero v. State, I44 Md. App. 333, 354-57 (2002) (no error in admitting officer's testimony that identifying witnesses seemed "very certain" when making their identifications; this was not an evaluation of witnesses' credibility).

16. Lay opinion whether a revolving door moved easily, rapidly or slowly. Admit? Eyerly v. Baker, 168 Md. 599, 612-13 (1935).

17. Lay opinion whether a cornfield would have obscured view of oncoming train. Admit?

See Baltimore, C. \& A. Ry. v. Turner, 152 Md. 216, 223-25 (1927); McAdoo v. State ex rel. Kuntzman, 136 Md. 452, 459 (1920).

18. Lay opinion of son-in-law, who knew testatrix very well for many years, that she was a "staunch business woman." Admit?

Wagner v. Klein, $125 \mathrm{Md}$. 229, 234-35 (1915).

19. Mother's testimony as to whether daughter's behavior and demeanor changed after her alleged rape. Admit?

King v. State, 36 Md. App. 124, 135 (1977). 
20. Whether a car observed by witness, who was an experienced driver, could have stopped within certain distance. Admit?

Bozman v. State ex rel. Cronhardi, 177 Md. 151, 156-57 (1939).

21. Witness's opinion as to what was witness's attorney's purpose in advising her as he did. Admit?

Robinson v. State, 47 Md. App. 558, 571-73 (1981).

22. State trooper's testimony, based on seeing baggie, that contents of baggie were rocks of crack cocaine. Admit? That they looked like rocks of crack cocaine (and other circumstantial evidence was admitted to show that they were). Admit?

Robinson v. State, 348 Md. 104 (1997).

23. Mother's testimony that car crash was cause of her subsequent illness and of her needing a Caesarean for her ninth child. Admit?

Symington v. Graham, 165 Md. 441, 446-49 (1933).

24. Whether witness believed that work was done according to terms of contract. Admit?

County Comm'rs v. Bel Air Suburban Improvement Ass'n, 134 Md. 548, 552 (19 19).

25. Whether another witness testified truthfully. Admit?

American Stores Co. v. Herman, 166 Md. 312, 314-15 (1934).

26. Whether persons on surveillance videotape were defendants. Admit?

Ricks v. State, 312 Md. 11,31-32 (1988). Compare Cochrane v. McGinnis, 160 F. Supp. 2d 447, 450-52 (E.D.N.Y. 2001), aff'd on other grounds, 50 Fed. Appx. 478 (2d Cir. 2002).

27. Whether scaffolding over sidewalk made walking on sidewalk dangerous.

Admit?

Weilbacher v. J.W. Putts Co., 123 Md. 249, 267-68 (1914).

28. Whether an open suitcase smelled like oranges. Admit?

Smelled like marijuana? Admit? 
See Smith v. State, $182 \mathrm{Md} .176,183$ (1943) (proper to admit witness testimony that noise sounded like the breaking of cement; "Opinion, so far as it consists of a statement of an effect produced on the mind, ... [is] admissible whenever a condition of things is such that it cannot be reproduced and made palpable in the concrete to the jury. This is particularly true with regard to noises and odors.").

29. Officer asked to testify whether defendant "could have been" on PCP when arrested. Admit?

Beyv. State, 140 Md. App. 607, 622-25 (2001), cert. denied, 368 Md. 526 (2002).

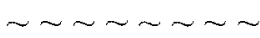

\section{Opinions in Out-of-Court Statements}

\section{$\S 1$. Opinions Contained in Admissions of Parties-Opponent}

Statements offered as admissions of a party opponent need not comply with the opinion rule, when they include the party-opponent's opinion. See 2 MCCORMICK ON EVIDENCE $\S 256$. A party is held responsible for statements of opinion he or she made. But cf. Briggeman v. Albert, 322 Md. 133, 139 (1991) (admission of evidence, as a statement by a party-opponent, that driver paid preset traffic fine would be prejudicial, "'backdoor' admission of a police officer's opinion of [the driver's] guilt").

Of course, unless the admission is a binding judicial admission, the party is free to deny making the statement or to explain why it was wrong.

The trial court, in its discretion under Rule 5-403, however, may exclude unhelpful or uninformed party admissions. See Suburban Hosp. Ass'n, Inc. v. Hadary, $22 \mathrm{Md}$. App. 186, 195 (1974) (in medical malpractice action, no error to exclude opinion of patient, expressed in course of a deposition, that "she didn't consider [doctor] at fault at all").

\section{§ 2. Other Out-of-Court Statements, Including Prior Consistent or Inconsistent Statements}

Generally, the opinion rule ought not be applied to exclude out-of-court statements, otherwise admissible either for impeachment purposes, as nonhearsay, or under exceptions to the hearsay rule, because those statements cannot be rephrased to be more factual. See State v. Jones, $311 \mathrm{Md}$. 23, 32-33 (1987). If, however, the statement contains both an opinion and the facts underlying it, the court, in its discretion under Rule 5-403, may redact the opinion. 


\section{§3. Expert Opinions Contained Within Out-of-Court Statements Falling under a Hearsay Exception, Such as Business Records}

Expert opinions that are contained in out-of-court statements that are not excluded by the hearsay rule generally will be admissible, if they appear to have been made by a qualified expert, with an adequate basis, on a proper subject, and would otherwise have been admissible, if the expert had testified to them. See 2 MCCORMICK ON EVIDENCE $§ 287$.

But if they appear to lack an adequate basis, or the opponent otherwise demonstrates that there is a genuine issue as to what opinion the expert held or whether it was valid, the court should require the expert to testify. See Shpigel v. White, $357 \mathrm{Md} .117$ (1999) (in hotly contested personal injury motor vehicle tort case, causation and damages could not be proved through medical records and bills, without live witness testimony regarding reasonableness of charges and need for treatment); Reynolds v. State, $98 \mathrm{Md}$. App. 348, 355-61 (1993) (reversible error to violate child sexual abuse defendant's confrontation right by admitting hospital records of his daughter's-the complaining witness'-stay in hospital psychiatric unit, when records contained doctors' opinions that defendant may have sexually abused her; confrontation right is violated if opinions appeared to lack a legally adequate basis as in this case, or if the opinion is too ambiguous to be helpful).

V. Telling the Chickens from the Eggs: Facts, Opinions, Experts, and Lay Witnesses

\section{$\S 1$. Of "Fact" Witnesses, "Opinion" Witnesses, "Testifying" Witnesses, and "Hybrid" Witnesses}

Just drawing the line between "facts" and "opinions" can be challenging. See Beech Aircraft Corp. v. Rainey, 488 U.S. 153, 167-69 (1988) (discussing the analytical difficulty in drawing a line between "fact" and "opinion"), on remand, 868 F.3d 1531 (11th Cir. 1989) (en banc).

\section{$\S 2 . \quad W h o$ May Testify as an Expert?}

Under Rule 5-702, the trial judge determines, in his or her discretion, whether a particular proffered expert witness is qualified to testify. As stated by Wigmore, the question for the trial court to consider in exercising this discretion is, "On this subject can a jury receive appreciable help from this person?"

Formal education is not required. Rule 5-702 refers to "a witness qualified as an expert by knowledge, skill, experience, training, or education. ..." For example, fisherman, plumbers, and teenaged computer hackers could all be possible experts, 
despite a lack of formal education. See Corsea v. Cruisers, a Division of HCS Int'l, Inc., 298 F.3d 13, 25-27 (1st Cir. 2002) (marine engines).

Sufficient case law has developed to guide counsel and the trial courts on many questions. For example, a general practitioner M.D. generally has been held to be acceptable to testify as to any medical field; a specialist is not required. Contra Ralston v. Smith \& Nephew Richards, Inc., 275 F.3d 965, 968-70 (10th Cir. 2001) (because proffered testimony must pass Daubert analysis in federal court, mere possession of medical degree does not qualify a physician to testify concerning any medical-related issue).

\section{Problems.}

30. Plaintiff calls an acupuncturist who had some college education but is not an osteopath, to testify to plaintiff's back injuries. Admit?

Uelandv. United States, 291 F.3d 993 (7th Cir. 2002).

31. Defendant wishes to call physicist to testify that fall from bunk bed could have caused injuries that killed defendant's toddler stepdaughter. Admit?

See Neverson v. Bessonnette, 242 F. Supp. 2d 78 (D. Mass. 2003) (on writ of habeas corpus).

32. Hospital billing manager is called to testify to necessity for medical procedures. Admit?

Desuav. Yokim, 137 Md. App. 138, 145-47 (2001).

33. Medical doctor is called to testify as an expert on life insurance. Admit? Wilson v. State, 370 Md. 191, 216 (2002).

34. Certified clinical social worker is called to testify as to mental disorders. Admit? In re Adoption/Guardianship No. CCJl47f6, 360 Md. 634, 648-49 (2000). 


\section{Procedure}

The proponent of an expert first must elicit the witness's qualifications on direct, then offer the witness as an expert in the designated field. The opponent may object, either on the ground that the subject matter is improper or that the witness is unqualified. With permission of the court, the opponent may voir dire the witness on these points -essentially during an interruption of the witness's direct examination.

If the court accepts the witness as an expert in the designated field, it will instruct the jury that the witness "has been accepted as an expert on [subject X] and is qualified to give his or her opinions on this subject."

- Note, however, that the Committee Note to the 2000 amendment to FRE 702 speaks favorably of District of Columbia's district Judge Richey's proposal that the witness be referred to not as an "expert," but rather as an "opinion witness." Might that be preferable? He also gives an immediate instruction upon qualification of an opinion witness, emphasizing that the jury is not bound by the witness' opinion. See Charles R. Richey, Proposals to Eliminate the Prejudicial Effect of the Use of the Word "Expert" under the Federal Rules of Evidence in Civil and Criminal Jury Trials, 154 FEDERAL RULES DECISIONS p. 537.

\section{§3. When is an Opinion Expert and When is it Lay and Why Does it Matter?}

- Rule 5-701 provides:

\section{Rule 5-701. OPINION TESTIMONY BY LAY WITNESSES}

If the witness is not testifying as an expert, the witness's testimony in the form of opinions or inferences is limited to those opinions or inferences which are (1) rationally based on the perception of the witness and (2) helpful to a clear understanding of the witness's testimony or the determination of a fact in issue.

- Rule 5-702 adds special requirements for expert testimony, and Rules 5-602,5$703,5-705$, and 5-706 provide special benefits regarding experts. (Rule 5-706 empowers the court to appoint its own experts, if appropriate, though commentators complain that this power is underutilized by judges.)

- Special discovery rules also apply re: experts. A resulting problem in federal courts led to amendment of FRE 701 so that it explicitly does not apply to "scientific, technical, or other specialized knowledge within the scope of Rule 702." See Certain Underwriters v. Sinkovich, 232 F.3d 200 (4th Cir. 2000) (reversible error to permit insurance investigator's opinions, regarding hypothetical use of anchor, as lay testimony under FRE 701). 
Maryland has seen no need for a similar amendment. Cf. Dorsey v. Nold, $362 \mathrm{Md} .241$ (2001) (reversible error not to permit medical malpractice plaintiffs to call medical examiner as expert in their case-in-chief, to testify that child died from asphyxia due to tumor's compression of airway; Rule 2-402(e)(1) did not require expert witness disclosure as to M.E., whose findings or opinions were not "acquired or developed in anticipation of litigation.").

\section{Problems.}

35. State trooper testified as a lay witness regarding accident. May he be crossexamined as if he had been qualified as an expert?

Goren v. United States Fire Ins. Co, 113 Md. App. 674 (1997).

36. ATF agent's testimony that guns in defendant's possession were not collector's items. Does this qualify as a lay opinion?

United States v. Conn, 297 F.3d 548 (7th Cir. 2002), cert. denied, 123 S. Ct. 1767 (2003).

37. Plaintiff ship repairer's employees and officers wish to testify that their charges were reasonable. Admissible as lay opinion, rather than expert?

Tampa Bay Shipwelding \& Repair Co. v. Cedar Shipping Co., 320 F.3d 1213 (11 th Cir. 2003).

\section{May/Must the Expert Testify at Trial as to the Details on Which the Expert's Opinion is Based?}

\section{$\S 1 . \quad$ Rule 5-702}

\section{Rule 5-702. TESTIMONY BY EXPERTS.}

Expert testimony may be admitted, in the form of an opinion or otherwise, if the court determines that the testimony will assist the trier of fact to understand the evidence or to determine a fact in issue. In making that determination, the court shall determine (1) whether the witness is qualified as an expert by knowledge, skill, experience, training, or education, (2) the appropriateness of the expert testimony on the particular subject, and (3) whether a sufficient factual basis exists to support the expert testimony. 


\section{§2. Rule 5-705}

\section{Rule 5-705. DISCLOSURE OF FACTS OR DATA UNDERLYING EXPERT OPINION.}

Unless the court requires otherwise, the expert may testify in terms of opinion or inference and give reasons therefor without first testifying to the underlying facts or data. The expert may in any event be required to disclose the underlying facts or data on cross-examination.

Rule 5-705 permits an expert to testify to an opinion or inference "without first testifying to the underlying facts or data, unless the court requires otherwise." This provision was intended to free counsel from having to relate lengthy, soporific hypothetical questions, which by prior case law had to include every material fact in evidence essential to the formulation of the expert's opinion, e.g., Mathieson Alkali Works v. Redden, $177 \mathrm{Md} .560$ (1940), before permitting the expert to testify to his or her opinion.

- Still, what reason to have the expert state his or her basis, at least in general terms, is supplied by Rule 5-702?

- What tactical reason may remain that will encourage counsel to have his or her expert testify to the underlying facts or data?

\section{Quaere:}

Suppose that the court accepts plaintiff's physician as an expert in the field of medicine. Plaintiff's counsel, having so qualified the witness, then abruptly asks the witness, "Do you have an opinion to a reasonable medical certainty as to the permanence of the plaintiff's injuries?"
A. "Yes."
Q. "What is that opinion?"

Defense counsel: "Objection! Counsel is required to lay a factual basis for that opinion first!" Would you allow the question?

- What if the underlying data are inadmissible as substantive evidence? 


\section{§3. Rule 5-703}

\section{Rule 5-703. BASES OF OPINION TESTIMONY BY EXPERTS.}

(a) In general.

The facts or data in the particular case upon which an expert bases an opinion or inference may be those perceived by or made known to the expert at or before the hearing. If of a type reasonably relied upon by experts in the particular field in forming opinions or inferences upon the subject, the facts or data need not be admissible in evidence.

(b) Disclosure to jury.

If determined to be trustworthy, necessary to illuminate testimony, and unprivileged, facts or data reasonably relied upon by an expert pursuant to section (a) may, in the discretion of the court, be disclosed to the jury even if those facts and data are not admissible in evidence. Upon request, the court shall instruct the jury to use those facts and data only for the purpose of evaluating the validity and probative value of the expert's opinion or inference.

(c) Right to challenge expert.

This Rule does not limit the right of an opposing party to cross-examine an expert witness or to test the basis of the expert's opinion or inference.

Committee note. -- Subject to Rule 5-403, and in criminal cases the confrontation clause, experts who rely on information from others may relate that information in their testimony if it is of a type reasonably relied upon by experts in the field. If it is inadmissible as substantive proof, it comes in merely to explain the factual basis for the expert opinion. The opposing party then is entitled to an instruction to the jury that it may consider the evidence only for that limited purpose. See, e.g., Maryland Dept. of Human Resources v. Bo Peep Day Nursery, 317 Md. 573 (1989); Attorney Grievance Commission v. Nothstein, 300 Md. 667 (1984); Beahm v. Shortall, 279 Md. 321 (1977); Hartless v. State, 327 Md. 558 (1992).

\section{a. Permissible Basis}

An expert's opinion may have either one or several bases, which must suffice to provide a rational basis for his or her opinion, which in turn is relevant to the substantive evidence developed in the case.

Like the opinions of a lay witness, an expert's opinions may be based on firsthand knowledge, such as examination of the personal injury plaintiff.

But, because experts are freed from the first-hand knowledge requirement (see Rules 5-602 and 5-703), the expert's opinion also may have a hearsay basis. (Rule 5-703 does not mean, however, that one may call an "expert" who simply parrots another's opinion, without adding anything of his or her own.) See Jackson v. Jackson, $249 \mathrm{Md}$. 170,174 (1968) (expert opinion as to testator's mental incapacity inadmissible when merely based on opinions of other experts in records proffered in evidence). 
The hearsay basis may be simply other witnesses' testimony in the case, that the expert has heard at trial. It may be out-of-court statements falling within exceptions to the hearsay rule.

But, under Rule 5-703, it also may be data inadmissible in evidence, that is reasonably relied upon by experts in the field. For example, a psychiatrist may rely on a psychologist's report, even though that report was prepared in anticipation of trial and would not qualify under the hearsay exception for business records.

Often an expert's opinion will be based on a combination of first-hand knowledge and hearsay. For example, the explosives experts who investigated the October 2000 attack on the U.S.S. Cole in Aden, Yemen, would have relied on both hearsay and their own personal examination of the ship. Whether particular information is reasonably relied on by the expert is to be determined by the court as a preliminary question of fact under Rule 5-104(a). See Hartless v. State, 327 Md. 558 (1993). See also United States v. Brown, 299 F.3d 1252, 1256-58 \& n.3 (11th Cir. 2002) (DEA agent's opinion as to value of cocaine base in Bermuda was properly based in part on other agent's information from Bermuda authorities), vacated on other grounds, 123 S.Ct. 1928 (U.S. 2003), on remand, 2003 WL 21983029 (11th Cir. 2003).

\section{b. For the Jury's Ears?}

The question arises whether the jury should be informed of reasonably relied upon but substantively inadmissible hearsay on which an expert has relied.

- What are the risks in admitting it, even with a limiting instruction that it is admitted not for its truth, but only for the limited purpose of explaining the basis of the expert's opinion?

- What are the risks in excluding it?

Md. Rule 5-703(b), which was derived from the corollary Kentucky rule and became effective with the rest of Title 5 on July 1, 1994, leaves the question of disclosure of a substantively inadmissible hearsay basis to the discretion of the court, but cautions that it may be admitted only if the underlying basis is "determined to be trustworthy, necessary to illuminate testimony, and unprivileged. ..." See Milton Co. v. Council of Unit Owners of Bentley Place Condominium, $354 \mathrm{Md}$. 264, 276-77 (1999) (no abuse of discretion to admit, for this purpose, surveys interpreted by experts, so that jury could evaluate conflicting experts' testimony). A limiting instruction will be given only on request.

Interestingly, FRE 703 followed suit in 2000, when it was amended by adding the following italicized language, so that, like Md. Rule 5-703, it cautions the judge against 
admitting nonsubstantive evidence offered solely to show the basis of expert opinion testimony, unless sufficiently necessary and helpful for that purpose:

\section{Fed.R.Evid. 703. Bases of Opinion Testimony by Experts}

The facts or data in the particular case upon which an expert bases an opinion or inference may be those perceived by or made known to the expert at or before the hearing. If of a type reasonably relied upon by experts in the particular field in forming opinions or inferences upon the subject, the facts or data need not be admissible in evidence in order for the opinion or inference to be admitted. Facts or data that are otherwise inadmissible shall not be disclosed to the jury by the proponent of the opinion or inference unless the court determines that their probative value in assisting the jury to evaluate the expert's opinion substantially outweighs their prejudicial effect.

(2000 amendment italicized.)

\section{Opinions on Ultimate Issues: Rule 5-704}

\section{$\S 1$. General Test: Helpful and Having a Sufficient Basis \\ Rule 5-704. OPINION ON ULTIMATE ISSUE.}

(a) In general. Except as provided in section (b) of this Rule, testimony in the form of an opinion or inference otherwise admissible is not objectionable merely because it embraces an ultimate issue to be decided by the trier of fact.

Rule 5-704 addresses whether an opinion on an ultimate issue may be admitted, e.g., defectiveness of a product. Rule 5-704(a) treats experts just as it does lay witnesses: the question is always merely one of whether the opinion is rationally based and will be helpful to the trier of fact. See Rules 5-701 and 5-702. If it would not be helpful, it is inadmissible.

\section{Problems.}

38. Lay witness's testimony to meaning of clause in testator's will. Admit?

Conrades v. Heller, 119 Md. 448, 452 (1913).

39. Plaintiff offers expert opinion that city violated Fair Housing Amendments Act in shutting off water to two newly constructed group homes for developmentally disabled adults, when City argued that developer had breached contract. Admit?

Good Shepherd Manor Foundation v. City of Momence, 323 F.3d 557 (7th Cir. 2003).

$-18-$ 
40. Expert testimony offered as to reasonableness of defendant police officer in releasing police dog on suspect. Admit?

United States v. Mohr, 318 F.3d 613, 622-25 (4th Cir. 2003), cert. denied, 123 S. Ct. 1644 (2003).

41. In money laundering case, accused wishes to call psychologist to testify to his assessment of key government witness's personality disorders and the effect these disorders have on her ability to perceive, recall, and recount events accurately, including her ability to distinguish fact from fantasy; opinion is based on her medical records and on observing her demeanor while testifying. Admit?

United States v. Falcon, 245 F.Supp.2d 1239 (S.D. Fla. 2003).

\section{§2. Accused's Mental State that is an Element of the Charged Crime: No}

Rule 5-704(b) Opinion on mental state or condition. An expert witness testifying with respect to the mental state or condition of a defendant in a criminal case may not state an opinion or inference as to whether the defendant had a mental state or condition constituting an element of the crime charged. That issue is for the trier of fact alone. This exception does not apply to an ultimate issue of criminal responsibility.

Rule 5-704(b) carves out one clear rule applicable in criminal cases: experts may not testify as to whether a criminal defendant had a "mental state or condition constituting an element of the crime," such as intent, premeditation, or malice. Nor, in an entrapment defense case, may an expert testify as to whether the accused had a predisposition to commit the crime. This portion of Rule 5-704(b) is substantively identical to the corollary provision of FRE 704(b).

See, e.g., United States v. Seschillie, 310 F.3d 1208 (9th Cir. 2002) (defense expert properly permitted to testify to factors relevant to accidental discharge of a gun, and properly precluded from testifying to whether the shootings at issue were accidental or contained those factors); Hartless v. State, 327 Md. 558 (1992) (proper to have excluded psychiatrist's opinion as to defendant's actual intent at time of killing); Simmons v. State, 313 Md. 33, 47-48 (1988) (error in excluding, in support of imperfect self-defense, testimony that defendant's subjective belief that force was necessary to prevent imminent death or serious bodily harm was consistent with defendant's psychological profile; no error in excluding testimony that defendant in fact had such subjective belief at time of offense). Cf. Whittington v. State, $147 \mathrm{Md}$. App. 496, 536-39 (2002), cert. denied, 373 Md. 408 (2002) (proper to decline to permit defense psychiatrist to testify as to voluntariness of confession).

Expert testimony concerning "general criminal practices" is not precluded. United States v. Bailey, 319 F.3d 514, 521-22 (D.C. Cir. 2003). See Shemondy v. State, 
147 Md. App. 602 (2002) (police sergeant's expert testimony regarding use of pagers and codes in drug usage and drug trafficking).

\section{§3. Accused's Sanity or Insanity: Federal Rules No, Maryland Yes}

FRE 704(b), "the Hinckley amendment," was added in 1984, after John Hinckley's trial for the attempted assassination of President Reagan in an effort to obtain the affections of actress Jodie Foster. Hinckley was found to be insane and confined to St. Elizabeth's Hospital. Members of the psychiatric community subsequently objected that they should not be asked to testify to the ultimate legal issue, as they were in Hinckley. FRE 704(b) precludes experts from testifying in federal court to the ultimate issue of an accused's criminal responsibility or lack thereof. In federal court, their testimony must stop one step before that ultimate conclusion.

The last sentence of Md. Rule 5-704(b), on the other hand, is dramatically opposite. In line with a longstanding Maryland statute, experts in Maryland state court are permitted to testify to whether an accused who has raised the insanity ("lack of criminal responsibility") defense had the capacity to conform his or her conduct to the requirements of the law.

\section{Sufficient Basis for Expert Testimony}

\section{$\S 1$. When Caesar Has Spoken, and Statutes Establish the Parameters, We Follow Caesar}

Statutes apply to a number of areas of expert testimony. E.g., MD. CODE ANN., CTS. \& JUD. PROC. § 10-916(b) (battered spouse syndrome).

Expert testimony contradicting the premise underlying a statutory presumption is inadmissible. City of Frederick v. Shankle, 367 Md. 5 (2001) (trial court properly precluded expert's testimony that rejected premise underlying Md. Labor \& Empl. Code Ann. $\S 9-503$ presumption, that, because of stress of police work, police officers who have heart disease are suffering from an occupational disease; expert could have testified only if he had simply attributed claimant's heart disease to other factors, and not that stress never causes heart disease). Cf. Beatty v. Trailmaster Products, Inc., $330 \mathrm{Md} .726$ (1993) (expert's opinion that the bumper height of defendant's vehicle was foreseeably unsafe and unreasonably dangerous lacked sufficient basis where the bumper height complied with a statutory standard, and the expert neither cited a developing consensus nor sound data to buttress his opinion). 
§ 2. As to Areas of Expert Testimony Not Governed by Statute Maryland Follows a 5-401, 5-702, 5-403 Analysis (Except With Regard to "Novel" (Not Previously Generally Accepted) Scientific Principles or Theories, as to Which It Follows Frye-Reed in Applying Rule 5-702, see Part X)

a. Is the proffered evidence relevant to the case, under Rule 5-401? See, e.g., Fisher v. State, $367 \mathrm{Md}$. 218,267-79 (2001) (passive personality irrelevant, as defendant's subjective intent was irrelevant to child abuse charge). This is what Judge Grimm calls "the fit" of the testimony.

A factual hearsay basis, inadmissible as substantive evidence, cannot be used to make the resulting opinion relevant. If there is no substantive evidence admitted that would make the opinion relevant - i.e., the opinion is based upon an entire scenario unsupported by substantive evidence, neither the opinion nor the basis will be admissible. Hartless v. State, $327 \mathrm{Md}$. 558, 575-81 (1992); Waltermeyer v. State, $60 \mathrm{Md}$. App. 69, 75-80 (1984) (non-treating physician may not testify to opinion based on hearsay related by patient, his wife and his sister, none of whom testified, totally unsupported by evidence). Accord Burns v. Secretary of Dept. of Health \& Human Services, 3 F.3d 415 (Fed. Cir. 1993).

\section{Problem.}

42. Race and sex discrimination plaintiff proffers an expert opinion that plaintiff suffers from Post Traumatic Stress Disorder, in part caused by events that were not discriminatory. Admit?

Neely v. Miller Brewing Co, 246 F.Supp.2d 866 (S.D. Ohio 2003).

b. Under Rule 5-702:

(1) Is the witness qualified as an expert by knowledge, skill, training, or education? and

(2) Is expert testimony appropriate on the particular subject? and

(3) Does a sufficient factual basis exist to support the expert testimony?

See, e.g., Evans v. State, 332 Md. 24 (1991) (trial court correctly concluded that "amnesic episode" was legally insufficient foundation for psychiatrist's conclusion that accused suffered from a "mental disorder" as defined under Md. Health Gen. Code Ann. $§ 12-$ 
108); Bohnert v. State, 312 Md. 266 (1988) (under circumstances, admitting expert opinion that child had been sexually abused was an abuse of discretion, as it had insufficient basis, i.e., only what victim had said; as an "alternative reason," the opinion was inadmissible "as a matter of law," because it was an opinion that the child's testimony was credible); Ford Motor Co. v. Wood, 119 Md. App. 142-43 (1998) (proper to exclude expert's testimony that products other than defendants' caused decedent's mesothelioma, as it lacked sufficient factual basis).

\section{Problems.}

43. Plaintiff patron of Splash Mountain was injured when riding the Cannonball Slide. She offers expert testimony regarding defendant's duty to warn of the specific dangers of that slide and to instruct patrons to keep their knees tucked when entering the catch pool. Her expert was a private investigator, experienced in recreational facility construction and maintenance, who went down the slide 6 to 12 times in different positions, but was uninjured. Admit?

Stolting v. Jolly Roger Amusement Park, Inc., 37 Fed.Appx. 80 (4th Cir. 2002) (per curiam) (unpublished).

44. In drug distribution prosecution, informant is called to testify that defendant understood that conversation between the two, though purportedly about an asbestos removal job, was really a coded discussion of a drug deal. Sufficient to admit?

United States v. Garcia, 291 F.3d 127, 139-43 (2d Cir. 2002).

45. To prove that asbestos release occurred between 1978 and 1991, results of dust sampling tests conducted between 1996 and 2002. Admit?

Port Authority v. Affiliated FM Ins. Co., 245 F.Supp.2d 563 (D.N.J. 2001), aff'd, 311 F.3d 226 (3d Cir. 2002).

46. Plaintiff offers expert testimony that Philip Morris could have used one of several feasible alternative designs that would have reduced the cancer risk of its cigarettes. There has been no animal testing of these designs and their impact on the cancer rate. Admit?

Labelle ex re. Labelle v. Philip Morris, Inc., 243 F.Supp.2d 508 (D.S.C. 2001). 
47. Officer's testimony that he could identify crack cocaine in a pat-down. Admit? Jones v. State, 343 Md. 448, 461-65 (1996).

48. State trooper's opinion that, based on HGN test of driver, driver had a specific level of blood alcohol. Admit?

Wilson v. State, 124 Md. App. 543 (1999).

c. Even if the evidence passes muster under Rules 5-401 and 5-702, should the trial court exclude it in its discretion under Rule 5-403?

Rule 5-403 provides:

\section{Rule 5-403. EXCLUSION OF RELEVANT EVIDENCE ON GROUNDS OF PREJUDICE, CONFUSION, OR WASTE OF TIME.}

Although relevant, evidence may be excluded if its probative value is substantially outweighed by the danger of unfair prejudice, confusion of the issues, or misleading the jury, or by considerations of undue delay, waste of time, or needless presentation of cumulative evidence.

An eyewitness identifies the accused as the perpetrator of the charged robbery. The defense is an alibi. The defense wishes to call a psychologist to testify to the frailties of eyewitness testimony. Admit? What are the relevant considerations?

Maryland appellate courts have not definitely ruled whether expert testimony about the frailty of eyewitness testimony is admissible. In Bloodsworth v. State, $307 \mathrm{Md}$. 164 (1986), the Court of Appeals held that the trial court's exclusion of such testimony was not an abuse of discretion. Other jurisdictions' decisions are divided on this question. See, e.g., United States v. Mathis, 264 F.3d 321, 333-44 (3d Cir. 2001), cert. denied, 122 S.Ct. 1211 (U.S. 2002) (under circumstances, harmless error to exclude bank robbery defendant's proffered expert testimony on memory, intended to counter police officer/eyewitness's identification, concerning likelihood that officer had focused on gun in suspect's hand); United States $v$. Sullivan, 246 F.Supp.2d 696 (E.D. Ky. 2003) (after Daubert hearing, plaintiff's motion to exclude expert testimony regarding theories of memory and their impact on the reliability of eyewitness identification was denied); People v. Lee, 96 N.Y.2d 157, 750 N.E.2d 63 (2001) (trial court acted within its discretion in excluding expert testimony regarding reliability of eyewitness identifications).

But the Court of Appeals of Maryland has held that the trial judge has a duty to thoughtfully exercise his or her discretion as to whether to give the pattern jury instruction regarding eyewitness identification. Gunning v. State, 347 Md. 332, 374 (1997) (failure to exercise discretion was reversible error). 
d. This 401-702-403 analysis is the approach followed by the federal courts, as to all expert testimony. But with regard to novel, scientific evidence, Maryland follows instead the heightened standard of Frye-Reed.

\section{Scientific Evidence: A Subcategory of Expert Opinion Evidence}

\section{$\S 1$. Three Prerequisites for Admissibility}

Scientific evidence is a subcategory of expert opinion evidence. When scientific evidence is offered, three foundational prerequisites must be laid:

1. The process used to obtain the results that are being proved is sound in principle (Rule 5-104(a));

2. The person following this process or principle was qualified (Rule 5104(a); and

3. The test, etc., was performed properly in this case, on proper equipment, if applicable, in good working order (Rule 5-104(b)).

\section{a. The Second and Third Requirements}

The second and third requirements are relatively straightforward in general. They also are the subject of numerous statutes governing specific types of evidence, such as blood and breath tests for alcohol. Some of the statutes create presumptions of admissibility, which put the ball in the accused's court to request the presence at trial of the State's expert.

\section{b. The First Requirement: Soundness of the Underlying Principles}

\section{Recognition by Statute}

With regard to the first requirement, the soundness of a number of scientific principles is governed by statute. In Maryland, these include, for example, radar, blood and breath tests for alcohol, certain DNA tests, and human leukocyte antigen blood tests for paternity.

\section{Example: DNA Evidence}

Md. Code Ann., Cts. \& Jud. Proc. § 10-915(c) provides for the admissibility of a DNA profile (an analysis of DNA identifying an individual's patterned chemical structure 
of genetic information) "to prove or disprove the identity of any person" in a criminal proceeding.

The Court of Appeals has held that this statute applies only to DNA tested by the restriction fragment length polymorphism (RFLP) technique; testing using the PCR technique must be evaluated under Frye-Reed. Williams v. State, 342 Md. 724 (1996).

In Amstead v. State, 342 Md. 38 (1996), the Court of Appeals held (over the dissent of now C.J. Bell) that, because DNA evidence collected using the RFLP technique is made admissible by statute, generalized challenges to its admissibility are precluded. The statute also makes admissible expert testimony to statistics showing the odds of a random match under either the "product rule" or the "ceiling principle" method (in Amstead, 1 in 480,000,000 and 1 in 800,000, respectively). The statute precludes exclusion under Md. Rule 5-403: DNA evidence may be excluded only if it is irrelevant, or if case-specific defects in the testing procedure make particular limits unhelpful. The trial judge must permit the defense to cross-examine a State's DNA expert about testing errors and incidents of contamination at the lab in question. Williams.

Thus, the statute does not preclude a trial judge from excluding evidence of a DNA profile if the court concludes that the laboratory in question did not follow proper procedures, so that the test results are unhelpful. See also United States v. Jacobus, 955 F.2d 786, 791-800 (2d Cir. 1992).

In 2003, the General Assembly substantially revised Maryland's statutes pertaining to the collection, testing, and preservation of DNA samples. S.B. 363 (Md. 2003), amending Md. Ann. Code Crim. Pro. \$ 8-201 and Md. Ann. Code, Public Safety $\S \S 2-501,2-502,2-504,2-505$, and 2-510, effective Oct. 1, 2003.

\section{Problem.}

49. State produces a letter from the testing laboratory that the analysis was validated (as required by Md. Ct. \& Jud. Proc. $§ 10-915$ ) according to standards established by the Technical Working Group on DNA Analysis Methods (TWGDAM); or the DNA Advisory Board of the Federal Bureau of Investigation. Defense moves for a pretrial hearing on whether the tests were so approved. Must the court grant

\section{the motion?}

Robinson v. State, 151 Md. App. 384, 395-97 (2003). 
When the soundness of the underlying principle is not recognized by statute, there are two other possibilities.

\section{Judicial Notice}

If sufficiently well established, it may be judicially noticed either through common general knowledge (e.g., the uniqueness of fingerprints) or by resort to indisputable sources. See Rule 5-201(b) (judicial notice is appropriate of facts that are "not subject to reasonable dispute" because they are either (1) "generally known within the territorial jurisdiction of the trial court" or (2) "capable of accurate and ready determination by resort to sources whose accuracy cannot reasonably be questioned."

(Note that, in federal court, fingerprinting may not so easily pass muster.) Compare United States v. Llera Plaza, 179 F.Supp.2d 523 (E.D.Pa. 2002) (case in which the court had initially excluded opinion that fingerprint came from a particular person) with, e.g., United States v. Sullivan, 246 F.Supp.2d 700 (E.D.Ky. 2003) (ACE-V methodology for fingerprinting, as practiced by F.B.I., satisfies Daubert). A divided panel of the United States Court of Appeals for the Fourth Circuit has upheld, against a Daubert challenge, the admission of expert testimony regarding both fingerprints and handwriting. United States v. Crisp, 324 F.3d 261 (4th Cir. 2003), cert. filed (U.S. June 2003).

\section{Example: Probability Evidence}

Under generally accepted statistical theories, the likelihood of a particular event is the product obtained by multiplying the probability of each of its independent components. For example, the likelihood of rolling a 1 (or $2,3,4,5$, or 6 ) on a die is $1 / 6$. The likelihood of rolling "snake eyes" on two dice is $1 / 6 \times 1 / 6=1 / 36$.

- Should such probability evidence be admissible with regard, for example, to whether a perpetrator was someone other than the accused? Or whether an infant's death was accidental?

In People v. Collins, 68 Cal.2d 319 (1968), eyewitnesses testified that the charged robbery was committed by a white woman, who wore her blond hair in a ponytail, and a black man, who had a moustache and a beard. They fled in a partly yellow car. There was evidence that the defendants matched this description.

The State called a math professor who testified as follows:

Characteristic

Car with yellow

Man with moustache $\underline{\text { Probability }}$

$1 / 10$

$1 / 4$ 


$\begin{array}{ll}\text { Woman with ponytail } & 1 / 10 \\ \text { Woman with blonde hair } & 1 / 3 \\ \text { Black man with beard } & 1 / 10 \\ \text { Interracial couple in car in } & 1 / 1,000 \\ \quad \text { California in } 1968 & \end{array}$

Therefore, he testified, the odds of having a couple meet that description was $1 / 12,000,000(10 \times 4 \times 10 \times 3 \times 10 \times 1,000=12,000,000)$.

\section{Quaere. Is this admissible testimony?}

Note that it gets complicated without a math expert to explain it. The probability in this example is not quite the same as the odds. If there is 1 couple in 12,000,000 matching these characteristics, the probability that there is more than 1 is $41 \%$.

- Should the prosecutor be permitted to argue that, if we believe the eyewitnesses' testimony, the evidence shows that we are $99.99999 \%$ sure that the defendants were the robbers? Allow the argument? See Wilson v. State, 370 Md. 191 (2002).

Problem. (from Howard Raiffa, Decision ANALYsis, pp. 20-21 (Addison-Wesley 1968))

I have two canvas bags filled with poker chips. The first bag contains 70 green chips and 30 white chips, and I shall refer to this as the predominantly green (PG) bag. The second bag contains 70 white chips and 30 green chips, and I shall refer to this as the predominantly white (PW) bag. The chips are all identical except for color. I now mix up the two bags so that you don't know which is which, and I put one of them aside. Now suppose that you choose 12 chips at random from this remaining bag and it turns out that you draw eight green chips and four white chips.

- What do you think the probability is that the bag you have sampled from is predominantly green?

- Is it predominantly green by a preponderance of the evidence? By clear and convincing evidence? Beyond a reasonable doubt?

In Wilson v. State, 370 Md. 191 (2002), a father was charged with infanticide. Evidence showed that both that infant, and another infant fathered by the defendant, but 
with a different mother, had had sudden deaths in their cribs, when under the father's care. The trial judge admitted experts' testimony regarding their reliance on the probability, arrived at by using the product rule, of two SIDS deaths of infants having the same father. One prosecution expert concluded that the probability was 1 in 100,000,000; another testified that it was 1 in 4,000,000. The Court of Appeals reversed the father's conviction, on the grounds that the statistical evidence did not satisfy Frye-Reed: reviewing the issue de novo, the Court of Appeals found that because there were several studies suggesting that there might be a genetic component to SIDS, the children's deaths were not proved to be independent, and the product rule could not be used.

The prosecutor had remarked in closing argument that there was a one in 10 million chance-not that the deaths were not homicides-but that the accused was innocent. The Court of Appeals held that the prosecutors' remark was not cured by the trial judge's subsequent instruction.

\section{Problems.}

50. In an age discrimination suit, expert analyses from the year in which the plaintiff was fired conclude that $59.2 \%$ of the workforce were older, but that older employees accounted for $70.3 \%$ of those terminated in employer's reduction in force, and that there was a less than $5 \%$ probability that age was related to termination by chance. Admit?

51. The plaintiff also offers analyses from the following year, also comparing active exempt employees with employees selected for termination, but as to which the expert admitted that there were inadequacies in the population used and that the results would have been different had she been able to identify and exclude nonexempt employees from her analysis. Admit?

See Murphy v. General Electric Co., 245 F.Supp.2d 459 (N.D.N.Y. 2003).

\section{3. $\quad$ Frye-Reed}

But "novel" scientific evidence that has not been recognized by statute (e.g., voiceprint, lie detector tests, the causation of cancer by a particular agent), must be formally proved. The federal and Maryland rules have taken different paths regarding the proof required.

In Maryland state court, until a principle has been held to have gained general acceptance among scientists in the relevant field, testimony based upon that 
principle will be inadmissible. Once it has gained such acceptance, testimony based upon it will be admissible, as long as the expert is qualified, the evidence will be helpful, and is relevant to the other evidence in the case.

\section{$\S 2 . \quad$ Maryland State Court: Frye-Reed}

The leading and incredibly brief decision in Frye v. United States, 293 F. 1013

(D.C. Cir. 1923) concerned an early predecessor of the current polygraph test. It was held inadmissible, although it was the defendant who offered the evidence, as exculpatory.

Frye established a requirement that scientific evidence will become admissible only when the underlying principle or process has gained "general acceptance in the particular field in which it belongs." Under Frye, until the relevant scientists generally agree that the principle or process is sound, its results will be inadmissible.

Fifty-five years later, in Reed v. State, 283 Md. 374 (1978), a case involving a "voiceprint" offered by the prosecution, the Court of Appeals adopted the Frye test in a four to three decision.

- What policy arguments support Frye-Reed, which sets a high bar for admissibility of scientific evidence? (See majority opinion by Judge Eldridge, joined by Judges Cole, Drapps, and Levine.)

- What is the downside to having such a high standard to meet? (See Judge Smith's dissent, joined by Chief Judge Robert Murphy and Judge Orth.)

\section{\$3. Federal Court: Daubert Rejected Frye in Favor of a 401 Relevant - 702 Reliable - 403 Analysis Across the Board, as to All Expert Testimony}

Although the FRE went into effect in 1975, the federal courts were divided for 18 years as to whether the FRE had codified Frye or jettisoned it. In Daubert v. Merrill Dow Pharmaceuticals, Inc., 509 U.S. 597 (1993), the United States Supreme Court held that FRE 702 had overruled Frye. Daubert held, on the one hand, that the federal trial courts do have a gate-keeping function to exclude "junk science." But it also held that there is no hard and fast requirement that novel scientific evidence have gained general acceptance in its field before it will be admissible.

Rather, the test for admissibility is a flexible one, requiring FRE 401 relevance, FRE 702 reliability, and a final screening under FRE 403. The Daubert Court suggested that, in making its "gatekeeping" determination, the trial court consider, inter alia, whether the proffered expert's technique or theory (1) can be or has been tested in some objective sense, (2) has been subject to peer review and publication, and (3) has been generally accepted in the particular field; the court should also look at (4) the technique or theory's known or potential rate of error, and (5) 
standards and controls. No one factor provides a litmus test. Therefore, even evidence that has gained "general acceptance" may be excluded in federal court, just as evidence that has not gained "general acceptance" may be admitted in federal court.

In its decision in Kumho Tire Co. v. Carmichael, 526 U.S. 137 (1997), the Supreme Court made clear that this 401-702-403 analysis is not restricted to scientific evidence, but applies to any evidence offered under FRE 702. If the Rule's requirements are met, the expert's opinion need not be stated to be held to a particular standard, such as a "reasonable degree of certainty or probability." Samuel v. Ford Motor Co., 112 F.Supp.2d 460 (D.Md. 2000).

A 2000 amendment to FRE 702 codified the Supreme Court's decision in Daubert and its progeny by adding, as explicit conditions to the admission of expert testimony, that "(1) the testimony is based upon sufficient facts or data, (2) the testimony is the product of reliable principles and methods, and (3) the witness has applied the principles and methods reliably to the facts of the case." FRE 702 now reads:

\section{Rule 702. TESTIMONY BY EXPERTS}

If scientific, technical, or other specialized knowledge will assist the trier of fact to understand the evidence or to determine a fact in issue, a witness qualified as an expert by knowledge, kill, experience, training, or education, may testify thereto in the form of an opinion or otherwise, if (1) the testimony is based upon sufficient facts or data, (2) the testimony is the product of reliable principles and methods, and (3) the witness has applied the principles and methods reliably to the facts of the case.

The amendment made the federal rule more similar to the language of Md. Rule 5702 , which requires the court to find that expert testimony is appropriate "on the particular subject" and that "a sufficient factual basis exists to support the expert testimony." See Giant Food v. Booker, 2003 WL 22051771 (Md. App. Sept. 3, 2003) ("This court found that while Rule 5-702 does not specifically state that the expert testimony must be 'the product of reliable principles and methods,' Maryland case law interpreting Rule 5-702 requires such a foundation.").

But the third requirement went further than the Md. Rule. In this author's opinion, FRE 702(3) forces federal judges to become fact-finders under Rule 104(a) as to issues that ought to be resolved, in a jury trial, under Rule 104(b). If a reasonable jury could find that the witness has applied the principles and methods reliably, the evidence should come in (this is what would happen in Maryland state court).

Under Daubert, the federal district court must hold a pretrial hearing and make specific factual findings supporting its conclusion. Busch v. Dyno Nobel, Inc., 40 Fed. Appx. 947, 960-61 (6th Cir. 2002) (reversing and remanding due to failure to do so). 
The appellate standard of review under Daubert, as explained in, e.g., United States v. Young, 316 F.3d 649, 656 (7th Cir. 2002), is as follows:

We review the district court's implementation of the Daubert framework with respect to the admission of expert testimony de novo. Once we are convinced that the district court properly applied the Daubert framework, however, we review the decision to admit or exclude the expert testimony for an abuse of discretion.

\section{§4. The Maryland Rules of Evidence}

When adopting Title 5 of the Maryland Rules, the Court of Appeals of Maryland chose not to be explicit as to whether it would follow Daubert or instead retain the FryeReed standard. From 1994 to date there has been no indication of movement in Maryland away from Frye-Reed.

On the contrary, the Committee note to Md. Rule 5-702 was amended in 1999 to reaffirm Frye-Reed.

\section{Difficulties in Application of Frye-Reed}

\section{$\S 1$. When Frye-Reed Applies, Who is the Relevant Scientific Community?}

Must the evidence be accepted by scientists other than those working on developing that theory or principle?

\section{§2. Appellate Review}

a. Failure to apply Frye-Reed when applicable, or application of it (to exclude crucial evidence) when inapplicable, is likely to be a slam-dunk for reversible error. See Keene Corp. v. Hall, 96 Md. App. 644 (1993) (rejecting argument that Frye-Reed is inapplicable in civil cases and finding reversible error, in this civil case, to admit evidence that failed to meet the Frye-Reed test).

b. Standard of review, when Frye-Reed applies: Cobey v. State, 73 Md. App. 233, 239,244 (1987) (the standard of review is merely whether the trial court's finding is "against the weight of the evidence rather than whether it is clearly erroneous," but "the appellate court may consider evidence which was not presented to the trial court"), cert. denied, 312 Md. 127 (1988).

\section{§3. The Biggest Brain-Teaser: When Does Frye-Reed Apply?}

a. The Reed majority, $283 \mathrm{Md}$. at 383, cited application of Frye by other states' courts to paraffin tests, medical testimony regarding the cause of birth defects, breath analysis devices designed to test for intoxication, truth serum injunctions, 
blood tests, neutron activation analysis, gunshot residue tests, Nalline tests for detection of narcotics use, ink identification tests, and hypnotism.

The Frye-Reed test has been applied in Maryland to, for example:

1. Hypnotically refreshed memory, Collins v. State, 296 Md. 670 (1983) (but C.J. Murphy, concurring and dissenting, dissented from the majority's application of the Frye-Reed test, since, in part, "the 'result' of hypnosis is not an assertion that the testimony is necessarily true or accurate").

2. Chromosome variant analysis, Cobey v. State, 73 Md. App. 233 (1987) (reversible error to admit State's expert testimony of C.V.A., not shown to have met Frye-Reed test, offered to show that rape defendant could have been father of victim's aborted fetus).

3. Polarized light microscopy, Keene Corp. v. Hall, 96 Md. App. 644 (1993) (reversible error to admit evidence of use of polarized light microscopy to identify asbestos fibers in tissue at the site of plaintiff's tumor; such use of PLM on a stained slide of human tissue was not shown to be generally accepted in the medical community; plaintiffs had offered a second expert's testimony that the underlying "physical principles" were very well accepted; Court of Special Appeals found that evidence was of a novel application of a scientific "technique," one different from that for which it was designed).

and even 4. Cadaver location by trained dogs, Clark v. State, $140 \mathrm{Md}$. App. 540, 57879, cert. denied, $368 \mathrm{Md} .527$ (2002).

But Frye-Reed has been held inapplicable to:

1. Opinion that alleged rape victim suffered from post-traumatic stress disorder (PTSD), State v. Allewalt, 308 Md. 89, 98, 110 (1986) (no abuse of discretion to admit that expert testimony; Frye-Reed standard does not apply to this medical opinion evidence, which was not "presented as a scientific test the results of which were controlled by inexorably physical laws;" in the future, "when ruling on whether to receive State proffered evidence of PTSD a trial judge will have to weigh the benefit of the evidence not only against potential unfair prejudice, but also against the complexity of possibly accompanying issues and against the time required properly to try the expanded case").

2. How asbestos directly causes cancer, Myers v. Celotex Corp., $88 \mathrm{Md}$. App. 442 (1991) (reversible error to apply Frye-Reed standard to doctor's 
opinion testimony, when doctor testified that his opinion rose to a "reasonable medical probability," "even though he could not state that the theory he espoused was generally accepted by the medical community"), cert. denied, 325 Md. 249 (1992).

3. Frailties of eyewitness testimony, Bloodsworth v. State, 307 Md. 164, 17786 (1986) (Frye-Reed test inapplicable to expert testimony as to frailties of eyewitness testimony, but no abuse of discretion in excluding evidence proffered by defense).

4. Field sobriety tests, Crampton v. State, $71 \mathrm{Md}$. App. 375, 386-88 (1987) (Frye-Reed test inapplicable to field sobriety tests given by police officers, which are "essentially empirical observations, involving no controversial, new, or 'scientific' technique. Their use is guided by practical experience, not theory;" evidence was admitted properly).

5. Compensable medical services, Sabatier v. State Farm Mutual Auto. Ins. Co., $323 \mathrm{Md}$. 232 (1991) (Frye-Reed test inapplicable in determining whether thermography is a valid diagnostic tool and is therefore compensable as a "necessary" and "reasonable medical service" within the coverage of the PIP statute).

6. The accuracy of particular products or devices used to apply sound scientific principles. Goldstein v. State, 339 Md. 563, 573 (1995).

\section{Problem.}

52. State calls Assistant Medical Examiner, who performed the autopsy, to testify that because of lack of swelling in baby's spinal cord, injuries to baby's head, neck, and spine occurred less than one hour before her death. Defense argues and presents expert testimony that experts in the field of forensic pathology do not accept the proposition that lack of swelling in the central nervous system can be used to determine the period of time within which the deceased was injured. Does Frye-Reed apply?

Giddens v. State, 148 Md. App. 407 (2002), cert. denied, 374 Md. 83 (2003) ("[B]ecause pathologists do agree that a properly performed autopsy will reveal lack of swelling in the brain and in the spinal column, an opinion [as to the time of injury] based upon that autopsy finding does not violate the Frye-Reed standard. *** "The logical corollary of the Frye test's focus on methodology rather than conclusions is that even unpopular conclusions are admissible so long as they are based upon generally accepted methodologies.") (quoting Kukn v. Sandoz Pharmaceuticals Corp, 270 Kan. 443, 14 P.3d 1170 (2000).

In contrast, Daubert would seem to apply to such an opinion offered in federal court. 


\section{b. Contrast with Daubert}

See, e.g., Soldo v. Sandoz Pharmaceuticals Corp., 244 F.Supp.2d 434-577 (NOT A TYPO: 143 pp. opinion) (W.D.Pa. 2003) (results of Daubert hearing on whether plaintiff's experts' opinions that her intracerebral hemorrhage was caused by her taking the drug Parlodel; court relied in part on three experts appointed by Court pursuant to Rule 706; court concluded that requirements of neither 702 nor 703 were met.)

Quaere. In Maryland, would Frye-Reed apply to an engineering expert's opinion regarding the defective design of a catheter inserted into the plaintiff's bladder?

Cf. McCorvey v. Baxter Healthcare Corp., 298 F.3d 1253 (11 th Cir. 2002) (excluding evidence, after Daubert analysis).

\section{On Which Side of the Fence is the Grass Greener, Frye-Reed or Daubert?}

\section{\$1. Should Maryland Stick with Frye-Reed?}

Requiring general acceptance will force us to wait longer to admit novel scientific evidence, even though it is reliable and will eventually gain general acceptance in its field.

One apparent advantage of the Daubert/Kumho Tire 401-702-403 test is that a similar approach may be used in all expert testimony situations, so that errors such as those in Myers and Sabatier for failing to apply Frye-Reed when it should be applied or vice-versa, can be avoided. But Daubert also has caused similar problems, as well as vastly multiplied lengthy pretrial hearings on expert testimony.

\section{§ 2. How About Half a Loaf? Should Frye-Reed's Requirement of "General Acceptance" Be Limited to Criminal Cases, Where a Person's Liberty or Life Is at Issue?}

See Sabatier v. State Farm Mutual Auto. Ins. Co., 323 Md. 232, 249 (1991) (The Reed court adopted the Frye test "deliberately . . to interpose a substantial obstacle to the unrestrained admission of evidence in criminal cases based upon new scientific principles.").

Another possible approach is that proposed by the Uniform Law Commissioners in 1998. Under this approach, Frye would provide the initial test, but a party dissatisfied with the result under Frye could challenge it by relying on the Daubert factors. 


\section{\$. Are the Bottom Lines Different under Frye-Reed and under Daubert?}

\section{a. Frye Appears Stricter on Its Face}

At first, many believed that Daubert would be more lenient than Frye-Reed. As examples of the differences in results under the federal and Maryland tests, consider that Maryland courts continue to find polygraph evidence strictly inadmissible even if the parties have stipulated to its admissibility. Cf. United States v. Scheffer, 523 U.S. 303 (1998) (Military Rule of Evidence excluding all polygraph evidence is not unconstitutional). On the other hand, some federal courts have begun to admit polygraph evidence under certain circumstances. Compare United States v. Tokars, 95 F.3d 1520, 1536 n.10 (11th Cir. 1996) ("Polygraph evidence may be admitted to impeach or corroborate testimony of a witness at trial within the court's discretion, so long as the opposing party has adequate notice of the evidence and an opportunity to secure its own polygraph.") with United States v. Prince-Oyibo, 320 F.3d 494, 496-501 (4th Cir. 2003) (several panels of the Fourth Circuit have announced a per se rule of exclusion of polygraph evidence, whether inculpatory or exculpatory), cert. filed (U.S. 2003). See United States v. Lea, 249 F.3d 632, 640 (7th Cir. 2001) (exclusion affirmed as not an abuse of discretion; but "[a] district court need not conduct a full Daubert analysis in order to determine the admissibility of standard polygraph evidence, and instead may examine the evidence under a Rule 403 framework. Nonetheless, we posit that the factors outlined by the Supreme Court in Daubert remain a useful tool for gauging the reliability of the proffered testimony, as reliability may factor into a 403 balancing test.").

Similarly, Reed found "voiceprint" evidence inadmissible because voiceprints had not achieved "general acceptance"; but the federal district court's admission of such evidence under a Daubert-type analysis was affirmed in United States v. Baller, 519 F.2d 463 (4th Cir. 1975), cert. denied, 423 U.S. 1019 (1975), a pre-Daubert case. Judge Butzner, writing for the panel in Baller, said:

\footnotetext{
Absolute certainty of result or unanimity of scientific opinion is not required for admissibility. *** Unless an exaggerated popular opinion of the accuracy of a particular technique makes its use prejudicial or likely to mislead the jury, it is better to admit relevant scientific evidence in the same manner as other expert testimony and allow its weight to be attacked by cross-examination and refutation.
}

519 F.2d at 466 . Under the federal approach to novel scientific evidence, a split of expert opinion merely affects the weight of the evidence, if it passes the 401-702-403 balancing test.

A number of other states, including California and Washington, have chosen to remain with Frye, though some others have chosen to follow Daubert. See Kathleen Eftimoff, The Decade after Daubert Proves Tough on Expert Witnesses, 27 LiTIG. NEws, No. 5, at 1,8 (July 2002) (plaintiffs choosing state courts where Frye applies). 


\section{b. But Frye Jurisdictions Are Not Always Stricter}

Often the results under Frye-Reed and Daubert will be the same. On remand in Daubert itself, the scientific evidence offered there (to show that a pregnant woman's use of Bendectin could cause birth defects) was still held inadmissible, under the new test. 43 F.3d 1311 (9th Cir. 1995).

And the application of Daubert to issues to which Frye-Reed does not apply may result in exclusion of evidence in federal court that has been admitted in state court. See $\S 4$ infra.

\section{$\S 4$. Burden on the Federal District Courts}

Chief Justice Rehnquist, concurring in part and dissenting in part in Daubert, complained that Daubert would require federal judges to become "amateur scientists." 113 S.Ct. at 2799, 2800. Despite talk of "federal science boards," to resolve certain scientific disputes, they have not materialized.

For example, Maryland's case law, Crampton v. State, 71 Md. App. 375 (1997) (results of field sobriety tests admissible) and Schultz v. State, $106 \mathrm{Md}$. App. 145, 164 (1995) (HGN results admissible), holds that Frye-Reed does not even apply to field sobriety tests performed by police officers. But Judge Grimm was required to perform a lengthy Daubert analysis on such evidence in United States v. Horn, 185 F.Supp.2d 530 (D.Md. 2002).

Judge Grimm concluded that the arresting officer could not refer, at trial on the merits (as opposed to the probable cause issue) to field sobriety tests - "walk and turn," "one leg stand," and "horizontal gaze nystagmus" - as tests, as they fail to meet Daubert standards when offered to prove blood alcohol content. The officer could testify to his observations:

In so doing, however, the officer may not use value-added descriptive language to characterize the subject's performance of the SFSTs, such as saying that the subject 'failed the test' or 'exhibited' a certain number of 'standardized clues' during the test; (5) If the Government introduces evidence that a defendant exhibited nystagmus when the officer performed the horizontal gaze nystagmus test, the defendant may bring out either during cross examination of the prosecution witnesses or by asking the Court to take judicial notice of the fact that there are many causes of nystagmus other than alcohol ingestion; and (6) If otherwise admissible under Fed.R.Evid. 701, a police officer may give lay opinion testimony that a defendant was driving while intoxicated or under the influence of alcohol. In doing so, however, the officer may not bolster the lay opinion testimony by reference to any scientific, technical or specialized information learned from law enforcement or traffic safety instruction, but must confine his or her testimony to helpful firsthand observations of the defendant. 


\section{Trends: Computers as Experts}

See, e.g., as to Computational fluid dynamics: Admission of evidence regarding expert's use of computer models to measure flow of air around and through a jet engine affirmed. Questions regarding correctness of models, etc., used went to weight of the testimony. Quiet Technology DC-8, Inc. v. Hurel-Dubois UK Ltd., 326 F.3d 1333 (11 th Cir. 2003), reh'g denied (11th Cir. 2003).

See Md. Rule 2-504.3. What has been your experience with computer analyses, animations, and simulations? 


\section{Answers to Problems.}

1. a. No.

b. Yes.

c. No.

d. Yes.

2. No.

3. Yes.

4. Yes.

5. Yes.

6. Yes. No.

7. Yes. No.

8. No.

9. Yes, admission aff ${ }^{\prime} \mathrm{d}$.

10. No: superfluous and overly influential. Rev'ble error to have admitted.

11. Error (tho' harmless) to have admitted.

12. Yes. Rev'ble error to have excluded.

13. This court said yes.

14. Admission aff'd.

15. Admission aff'd.

16. Yes.

17. Rev'ble error to exclude re: bean patch. Admissible re: train.

18. Yes.

19. Yes.

20. Yes.

21. No.

22. Rev'ble error to admit. Yes.

23. No.

24. No.

25. No.

26. Yes, if in better position than jury.

27. No.

28. Yes.

29. No.

30. No. Rev'ble error to have admitted.

31. No.

32. No.

33. No. Exclusion aff'd.

34. Yes. Trial court did not abuse its discretion in permitting a certified clinical social worker to testify as to mental disorders; fact that a statute, Md. Cts. \& Jud. Proc. Code Ann. $§ 9-102$, expressly authorizes licensed psychologists to testify "merely limits the court's discretion to deny a person in that class [see State v. Bricker, 321 Md. 86 (1990)] expert status for the 
purpose of testifying. When no such statute exists with regard to a person offered as an expert, however, the court has broad discretion to determine whether that person will be qualified as an expert or not.") As to licensed clinical social workers' ability to testify to mental diagnoses, see Md. Code Ann., Health Occ. § 19-101(m)(4)(ii).

35. No.

36. No, but admission aff'd as expert opinion.

37. Yes.

38. No.

39. No. Exclusion aff'd.

40. Yes. Admission aff'd.

41. No.

42. No.

43. No.

44. Rev'ble error to admit as lay opinion, where no foundation as to why defendant would know what informant meant.

45. No.

46. No.

47. No.

48. No.

49. No.

50. Yes.

51. No.

52. No. 